\title{
How Does Green Marketing Claim Affect Brand Image, Perceived Value, and Purchase Decision?
}

\author{
Indah Fatmawati, ${ }^{1,}$ and Muhammad Athar Alikhwan ${ }^{2}$ \\ ${ }^{1}$ Doctor of Management Study Program, Universitas Muhammadiyah Yogyakarta, 55183 Bantul, \\ Yogyakarta, Indonesia \\ ${ }^{2}$ Department of Management, Universitas Muhammadiyah Yogyakarta, 55183 Bantul, Yogyakarta, \\ Indonesia
}

\begin{abstract}
The rise of pro-environmental awareness has promoted a new innovative local brand that considers sustainable society life. This study analyses how the green marketing claim of new local cleaner products influences the brand image, perceived value, and consumer purchase decisions. The respondents of this study are consumers of local shoe cleaner products claimed as green ones. The setting is a new brand of shoe cleaner introduced in Yogyakarta, Indonesia. This brand is a green product developed with a green marketing program. Using the purposive sampling method, we chose one hundred fifty respondents. The data analysis is using Structural Equation Modelling (SEM) of AMOS 21. Our result shows that green marketing significantly impacts brand image, perceived value, and purchase decisions. Brand image and perceived value affect purchase decisions substantially.
\end{abstract}

\section{Introduction}

The issue of global warming has reminded people worldwide to take serious attention and action to contribute to saving the environments' efforts. In Indonesia, the government has also very concerned about environmental conditions. The government is responding by establishing regulations, such as Law number 32 of 2009, which explains that a good and healthy environment is the fundamental right of every Indonesian citizen. This regulation has inspired people to protect the environment by implementing the go green system in their daily lives. Every citizen can perform much pro-environmentally behavior to avoid the risk of global warming, such as buying a green product [1], reducing the use of electrical energy [2]. Another effort is to regulate companies to handle their waste. The government has established the regulation via the Republic of Indonesia Government Regulation of Article 1 paragraph 26 of 2014 about which stated that every people who run a business must get environmental permission by fulfilling all requirements regarding maintaining and managing the environment.

* Corresponding author; indahfatmawati@umy.ac.id 
In Indonesia, one of the most critical drivers of global warming comes from plastic waste pollution in the environment, caused by people's unconsciousness in disposing of garbage properly. The Special Region of Yogyakarta, Indonesia, is one of the cities that has experienced the highest increase in pollution. Starting from 2013 at the level of $78.5 \%$, until 2017, which reached $90.58 \%$. In 2016 it decreased by $4 \%$ from the previous year, it experienced a very drastic increase of up to $8 \%$ in the following year. Based on the Directorate General of Pollution and Environmental Damage Control of Indonesia, the safety limit of Yogyakarta ranges from $55-60 \%$ and this indicates that this city is still far from safe.

The abovementioned discussion implies that it is essential to improve consumer awareness of environmental pollution. It can be starting by changing the lifestyle to be more environmentally friendly in everyday life. Green marketing is a marketing attempt to initiate providing environmentally friendly products. Green marketing is not a new marketing concept introduced by Bell, Emeri, and Feldman in 1971. The marketing concept misconception, which is only limited to satisfying the desires of consumers and ignoring the interests of society and the long-term support, has become the driver of green marketing emergence.

The rise of the green marketing concept has promoted the image of the company/brand. Brand image is also essential in consumer decisions to buy a product. Brand image is the critical asset of which affects consumer interest. A good image will make consumer buying interest higher, and green products usually build an excellent product image that focuses on one thing, namely caring for the environment, to create a positive image for consumers. With that, consumers will decide to buy the product.

Apart from green marketing and brand image, perceived value also strongly influences consumer purchasing decisions. Perceptions of value will build consumer perceptions in choosing a product. It could be that the perception is negative, and it could also be that the perception is positive. Products promoted in green marketing are environmentally friendly products or can be said to be green products.

The research setting is a green product designated for shoe cleaning. The founder claimed this product would become Indonesia's most trusted natural-based and environmentally friendly shoe cleaning company. They have the vision to bring their product to become one that applies a green marketing system. This product is claimed as the first shoe cleaning liquid product in Indonesia which environmentally friendly.

\section{Literature Review}

\subsection{Green Marketing}

Environmental awareness has risen rapidly in recent years, as businesses have increasingly begun to include ecological protection concepts into their research and development (R\&D), manufacturing, and marketing operations [3]. According to American Marketing Association (AMA) [4], green marketing is a whole process of marketing that is safe for the environment. Green marketing is a broad term that refers to various activities such as product modification, improvements to the production line and packaging, and advertising changes or eliminating any action that harms the environment [5]. It stimulates green consumption behavior by encouraging consumers to buy green products, thus reducing pollution [3]. Therefore, green marketing can offer only environmentally friendly products and include the production process, packaging changes, and product modification activities. From a long-term perspective, all marketing practices meant to develop and assist all changes expected to satisfy human needs and aspirations with minimal impact on the 
natural environment are called green marketing [6]. However, like conventional marketing, green marketing also requires an innovative marketing mix of product, price, place or distribution channel, and promotion. The green marketing mix program involved several marketing decisions, including providing environmentally friendly products, setting premium prices, creating environmentally friendly distribution channels, and designing environmentally friendly advertisements [7].

\subsection{Brand Image}

Brand image is the initial consumers' perception when hearing the slogan, remembered and embedded in their minds [8]. It is the most efficient way to talk to consumers by translating a brand's different benefits [9]. It is also a critical feature indicating how consumers feel about a brand and whether a positive relationship exists between the brand and consumers [10]. Kotler and Keller added that brand image is the perception and belief held by consumers, as reflected in the associations embedded in consumers' memories. It includes inclusive sensory influence created by enterprises and accepted and recognized by consumers, which affects the brand association in consumers' retention [11]. The brand image showed a symbolic meaning related to the brand's specific attributes [12]. A brand equipped with symbolic (or social) benefits is designed to satisfy consumers' need for selfenhancement, role position, group membership, or ego identification [9]. Xian [9] argues that brand image consists of company, consumer, and product.

\subsection{Perceived Value}

Perceived value is a subjective concept determined by the various contexts. It could distinguish the characteristics of different products. It also refers to a consumer's personal opinion or general evaluation of the value of the purchased product or service and comparing the "profit and loss" [13]. Kotler and Keller [8] state that customer perceived values are the difference between prospective customer assessments of the benefits and costs of an offer. Customer perceived value works as a bridge between customer appraisal of green products and purchase behavior, thereby linking the consumer's attitudes to purchasing and psychological behavior during decision-making [14]. The buyer will choose from the many bids which he thinks are the most valuable. The indicators of this perceived value are worthiness, fair price, offering good value, and price compatibility with the product.

\subsection{Buying Decision}

Buying decisions of green consumers are the central topic in the current state of research on green consumer behavior [15]. Kotler and Keller [8] explain that the consumers' purchasing decisions are related to the kind, quantity, location, and other associated decisions in buying the products. The possibility of a consumer purchasing an eco-friendly product with a low environmental impact is called "green purchase intention" [12]. Many components influence consumer purchasing decisions. Purchase intention items capture respondents' willingness to purchase a specific brand as well as their willingness to repurchase it [16]. As stated by Kotler and Keller [8], there are seven components of the consumer purchasing decision structure, namely the type of product, the form of the product, the choice of brand, the place of sale, the number of products, the time of purchase, and the method of payment. 


\section{Method}

\subsection{The Effect of Green Marketing on Brand Image}

Grant [17] states that green marketing aims to communicate that the brand or company cares about the environment to create a positive image for consumers. Consumer awareness of saving the earth is currently rising, and many consumers have started to adopt a healthy life, such as using environmentally friendly green products. Consumers appreciate producers who provide a green product related to their needs and wants. Green production gives the company a competitive advantage, as many customers prefer eco-friendly products [11]. Jeong et al. [18] found that customers' perceptions of green practices positively influence a green image, influencing customer attitude towards the products. We then proposed the following hypothesis

H1: Green marketing positively affects brand image.

\subsection{The Influence of Brand Image on Purchasing Decisions}

Kotler and Keller [8] state that one of the purchase decision elements is product choice. Along with the rise of consumer awareness to use the green product and the increasing consumer appreciation toward green product providers, consumers will prefer brands that benefit their needs, are environmentally friendly and have a better brand image. These beliefs will influence consumers' purchase decisions. Zameer, Wang, and Yaasmeen [11] argued that an excellent green brand image plays a significant role in consumers' purchase decisions worldwide. According to Kumar and Ghodeswar [15], green consumers' buying decisions involve intrinsic and extrinsic factors such as realizing their environmental responsibilities, the quest for gaining knowledge, self-interest, and willingness to act for resource conservation, and reduced impact on the environment. Extrinsic factors to the consumers, for instance, are the social image of consumers and product characteristics (such as product quality, safety, performance, price, promotion, and impact on human health). Suki [19] states that marketers can use green brand positioning for marketing their products better, improving consumers' green brand knowledge and attitude toward green brands, and increase green brand purchase intentions. Brand image generates brand attitudes, which further create associations. Brand attitudes could, in turn, influence purchase intentions or repurchase intentions [16]. Therefore, we proposed the following hypothesis.

$\mathrm{H} 2$ : Brand image positively affects purchasing decisions.

\subsection{The Effect of Green Marketing on Perceived values}

Pujari, Wright, and Peattiestatestates that green marketing carried out by companies have a positive impact on the company, including increasing sales, improving customer feedback, being closer to customers, enhancing competitiveness, improving the company's image. Research conducted by Confente et al. [21] identified that a higher level of green selfidentity leads to a higher level of the perceived value of a product. Kumar and Noble [22] also identified value as a consumer behavior driver that serves as a criterion for defining preference and making judgments. Hence, we develop the following hypothesis.

H3: Green marketing has a significant effect on perceived value. 


\subsection{The Effect of Perceived values on Purchasing Decisions}

A good perception of value will make consumers more interested in consuming the product. Kotler [8] also explains that the more favorable an outcome is to the consumer, the more likely they make purchasing decisions. Healthy goods or environmentally friendly goods have become popular and often sought by consumers. Based on empirical results explored by Tsai et al. [3], purchase intentions can increase by providing more transparent, diverse environmental cues based on information technology and increasing consumers' knowledge of product certifications. We argue that the product with good consumer perceived value will influence them to make purchase decisions. Therefore, we develop the fourth hypothesis.

H4: Perception of value has a significant effect on purchasing decisions.

\subsection{The Effect of Green Marketing on Purchasing Decisions}

Consumer awareness to buy environmentally friendly products is rising. These phenomena will affect consumer interest to choose green products instead of conventional ones. The green product has become more attractive since its natural appeal [23], and it contributes to helping preserve the environment[24]. Such attractiveness can make consumers decide to buy green products. Green innovation can lead consumers to pay a higher environmental protection premium price, increasing consumers' green purchase intention [25]. Chen et al. [25] identified that by carrying out green innovation activities for the business support, a brand could make more consumers purchase ideas, implement purchase behavior, effectively achieve brand realization, and enhance brand competitiveness and market share. Based on this idea, we develop the following hypotheses:

H5: Green marketing has a significant effect on purchasing decisions.

\subsection{Research Model}

The conceptual framework is shown in Figure 1.

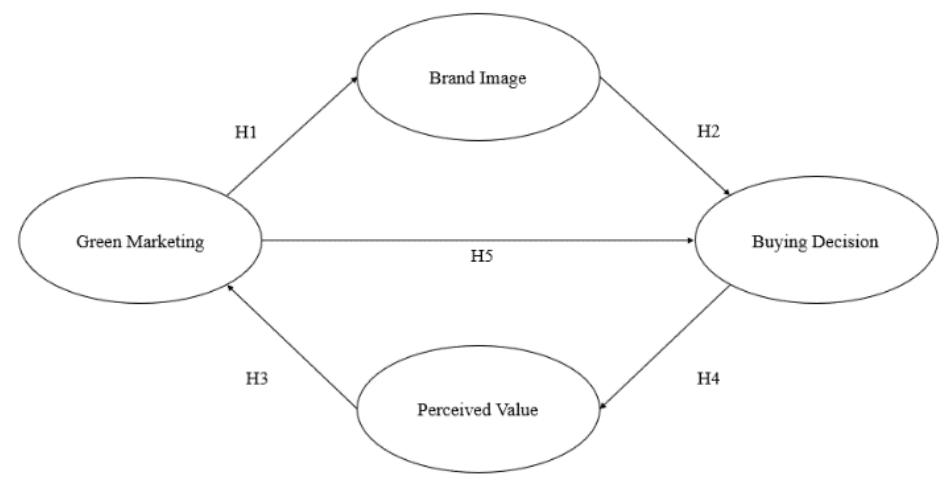

Fig 1. Research Model

\subsection{Research Method}

The research approach is quantitative with the explanatory strategy, which emphasizes explaining the causal relationship among concepts under investigation [26]. We collect the 
data using a field survey via questionnaire. The distribution of the questionnaire is using an online questionnaire.

The setting of this research is a new local green brand designated for shoe cleaners. The brand name is Andrrows, initially launched in Yogyakarta. Besides sell shoe cleaners, they also provide shoe cleaning services in their store. The founder of this brand claimed that this product is environmentally friendly. The founder conducted a green marketing mix concept by providing green products, promotion, and green distribution concepts. The production process reduced unsafe ingredients and claimed that the wastewater from the shoe washing process is safe to shower the plants safely. The promotion and product packaging also reduce unnecessary plastics and minimize the use of paper.

The respondents of this study were students in Yogyakarta who had bought and used Andrrows shoe cleaning liquid products and shoe cleaning services. Sample selection criteria are using purposive sampling, and the final usable sample size is 150 respondents. According to Hair et al.[27], the ideal number of samples used in a study with the complex model is between $100-200$.

Measurements of the construct refer to previous related studies. Green marketing measurement is referring and adapting from Sigh in nine items such as environmentally friendly products, premium price, ecologically friendly store, and promotion concept. Brand image measurement uses Xian's [9] company image, consumer image, and product image. While perceived value is using the size from Kotler and Keller [8] in four items, i.e., product feasibility, value offering, value for money, product-price feasibility. Finally, purchase decisions are measured

All variables in this study use a Likert scale, which measures respondents' from strongly disagree to strongly agree on a 5-point scale [26]. In most cases, the Likert scale assesses a person's attitudes, opinions, and perceptions about social events or symptoms.

\section{Results and Discussion}

\subsection{Results}

\subsubsection{Validity and Reliability Test}

The initial step of data analysis is testing the validity and reliability of the instruments. The validity test is measured using Confirmatory Factor Analysis. In comparison, the reliability test is conducted by measuring Cronbach Alpha. The loading factor criteria for the loading factors is higher than 0,5 . At the same time, the reliability test results are expected higher than 0.6 [27].

Table 1. Validity and Reliability Test Result

\begin{tabular}{|l|c|c|}
\hline \multicolumn{1}{|c|}{ Variable } & $\begin{array}{c}\text { Loading } \\
\text { Factor }\end{array}$ & $\begin{array}{c}\text { Construct } \\
\text { Reliability }\end{array}$ \\
\hline I love this product with eco-friendly packaging materials & 0.797 & \multirow{2}{*}{} \\
\cline { 1 - 1 } I think the ingredients used in these products are qualified & 0.804 & \\
\cline { 1 - 1 } The packaging is easy to recycle & 0.820 & \multirow{2}{*}{0.9412} \\
\cline { 1 - 2 } I am ready to pay more for these shoe cleaning fluids & 0.791 & \\
\cline { 1 - 2 } The price of these shoe cleaning fluids met my expectation & 0.815 & \\
\cline { 1 - 2 } These cleaning fluid products are easy to obtain or obtain & 0.745 & \\
\cline { 1 - 2 } The promotion is paperless. & 0.811 & \\
\cline { 1 - 2 } $\begin{array}{l}\text { The environmental message in the promotion is clear and easy } \\
\text { to understand }\end{array}$ & 0.820 & \\
\cline { 1 - 2 } Environmental promotion is honestly & 0.9019 \\
\hline This product is a shoe cleaning fluid & 0.804 & \\
\hline
\end{tabular}




\begin{tabular}{|c|c|c|}
\hline Variable & $\begin{array}{l}\text { Loading } \\
\text { Factor }\end{array}$ & $\begin{array}{l}\text { Construct } \\
\text { Reliability }\end{array}$ \\
\hline This product is environmentally friendly. & 0.747 & \multirow{9}{*}{0.9282} \\
\hline This product shoe cleaning fluid is a safe product & 0.786 & \\
\hline This product is a product with a premium price & 0.875 & \\
\hline This product is a premium product. & 0.809 & \\
\hline This product can clean shoes effectively & 0.802 & \\
\hline This product is a quality product. & 0.876 & \\
\hline The benefits provided by this product, worth the price & 0.800 & \\
\hline This product is a product that preserves the environment. & 0.873 & \\
\hline Waste produced by this product, safe for the environment & 0.892 & \\
\hline I bought this product to clean my shoes & 0.781 & \multirow{5}{*}{0.9114} \\
\hline I bought this product as a responsibility for the environment. & 0.837 & \\
\hline $\begin{array}{l}\text { I prefer this product over other products even though it is more } \\
\text { expensive. }\end{array}$ & 0.814 & \\
\hline $\begin{array}{l}\text { I prefer this product, which is already well known as an } \\
\text { environmentally friendly product. }\end{array}$ & 0.814 & \\
\hline $\begin{array}{l}\text { I prefer this product, which provides more benefits than other } \\
\text { products. }\end{array}$ & 0.855 & \\
\hline
\end{tabular}

Table 1 shows the results of the validity and reliability test. From 24 items tested are valid, based on the factor loading value $\geq$ of 0.50 [27]. The reliability test showed that the four variables are reliable based on the standard of the $\mathrm{CR} \geq 0.70$ [27].

\subsubsection{Hypotheses Testing}

The data analysis technique to test the research hypotheses is using Structural Equational Modelling (SEM), which encompasses seven steps according to Hair et al. [27] as follows:

\section{Step 1: Theory-Based Model Development}

The first step in the SEM model is to develop a research model based on the study's theoretical framework. Our research model consists of one exogenous (green marketing) variable, two mediating variables, brand image and perceived value, and an endogenous (purchase decision) variable.

\section{Step 2: Constructing a Path Diagram}

The second step is describing the research framework in a path diagram. Based on theory and previous studies, a path diagram was developed, as shown in Figure 2:

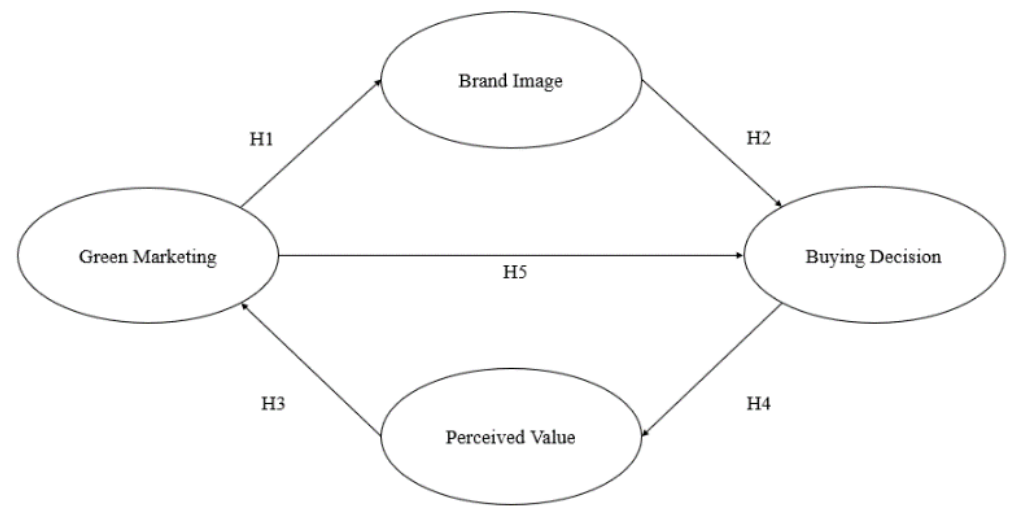

Fig 2. Path Diagram 


\section{Step 3: Converting the Path Diagram to Structural Equation}

The third step is converting the path diagram into equations, both structural equations, and measurement model equations as in Figure 3:

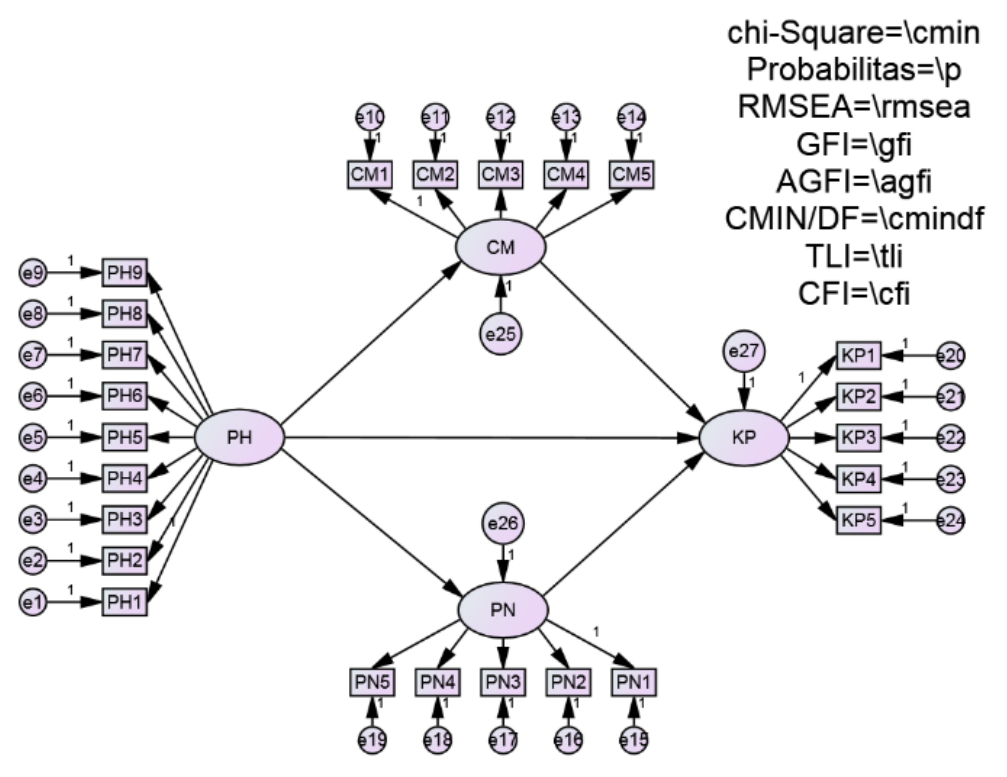

Fig 3. AMOS Output Research Model

Figure 3 shows a converted path diagram into structural and measurement model equations using IBM SPSS AMOS version 22. There are four variables: 1. green marketing (9 items), 2. brand image ( 5 items), and 3. perceived value (5 indicators). At the same time, purchase decision measurement $\mathrm{s}$ using five indicators.

\section{Step 4: Selecting Input Matrix Types and Estimates of the Proposed Model}

1. Input matrix

The next step is to enter the input data into AMOS, which converts the data into covariance or correlation matrix data. The covariance matrix input test confirms the relationships among variables.

2. Estimation of the proposed model

This study's structural equation model estimation technique is the Maximum Likelihood Estimate (MLE). The estimation of the model uses a minimum sample of 100-200 for good goodness-of-fit results [27]. Maximum Likelihood Estimate (ML) is operating on the following assumptions:

1. Large sample size

The total number of persons who took part in this study was 150 , which refers to the theory of Hair et al. [27], which argues that the number of representative samples is around 100-200. The sample size in this study has met the assumptions required in the SEM test.

2. Data normality test

The normality test uses the value of cr (critical ratio) for kurtosis (tapering) and skewness (slope) in the range of -2.58 to 2.58 . If the value of $\mathrm{cr}$ is greater than the critical value, the data distribution is not univariate normal [27]. Testing results from the data normality shown in Table 2 
Table 2. Data Normality Test

\begin{tabular}{|l|l|l|l|l|l|l|}
\hline Variable & $\min$ & $\max$ & skew & cr & kurtosis & cr \\
\hline KP5 & 2,000 & 5,000 & -222 & -1111 & -658 & $-1,646$ \\
\hline KP4 & 2,000 & 5,000 & -387 & $-1,935$ & -497 & $-1,243$ \\
\hline KP3 & 1,000 & 5,000 & -.511 & $-2,556$ & .077 & .192 \\
\hline KP2 & 1,000 & 5,000 & -427 & $-2,134$ & -287 & -718 \\
\hline KP1 & 1,000 & 5,000 & -.557 & $-2,784$ & .150 & .375 \\
\hline Multivariate & & & & & $\mathbf{- 1 1 , 6 8 0}$ & $\mathbf{- 2 , 0 2 5}$ \\
\hline
\end{tabular}

Table 2 shows the univariate normality test results, which indicated that most are normally distributed since the critical ratio (cr) for kurtosis and skewness are in the range of -2.58 to 2.58 . Therefore, the multivariate data has met the normal assumptions because the value of -2.025 is from -2.58 to 2.58 .

3. Identification of outliers

Outliers are conditions in which data has unique characteristics, is different from other observations, and appears extreme. In multivariate analysis, the presence of outliers was tested by looking at the Mahalanobis Distance Squared significance value of $\mathrm{p}$ $<0.001$. The distance is using X2 in degrees of freedom equal to the number of items in the questionnaire. This study uses 24 items of the questionnaire. Using the excel program, the Insert - Function - CHIINV sub-menu, we entered the probability and number of measured variables and got 51.178. It means that all data or cases whose value is more significant than 51.178 are multivariate outliers. Outliers test results showed in Table 3.

Table 3. Outliers Normality Testing

\begin{tabular}{|l|c|c|c|}
\hline Observation number & Mahalanobis d-squared & p1 & p2 \\
\hline Respondent 88 & 41,836 & .013 & .869 \\
\hline Respondent 113 & 40,354 & .020 & .794 \\
\hline Respondent 42 & 38,999 & .027 & .780 \\
\hline Respondent 89 & 37,467 & .039 & .844 \\
\hline
\end{tabular}

Table 3 shows the calculation of the outliers limit, the 88th respondent with a d-squared Mahalanobis value of 41.836 is the highest d-squared Mahalanobis value. Based on the results, there is no data greater than 51.178; there are no outliers' data.

\section{Step 5: Assess the Structural Model Identification}

The fifth step is to identify the model and check the identification results whether it is logical (meaningless). If there are unlogical results, then the research model has identification problems. The problem of identification is the inability of the proposed model to produce a unique estimate.

One of several ways to identify the identification problem is by look at the estimation results. SEM analysis requires the model's identification shows that the model is included in the category over-identified [27]. This identification is using the degrees of freedom of the model (see Table 4 and Table 5):

Table 4. Computation of Degrees of Freedom (Default Mode)

\begin{tabular}{|l|l|}
\hline A number of distinct sample moments: & 300 \\
\hline The number of distinct parameters to be estimated: & 53 \\
\hline Degrees of freedom $(300-53):$ & 247 \\
\hline
\end{tabular}


Table 5. Result (Default Model)

\begin{tabular}{|l|l|}
\hline the minimum was achieved & \\
\hline Chi-square & 379,587 \\
\hline Degrees of freedom & 247 \\
\hline Probability level & 0,000 \\
\hline
\end{tabular}

Table 4 and Table 5 showed that the value of the degrees of freedom is 247 or positive, and it means the model is over-identified and feasible to proceed to the next step.

\section{Step 6: Assessing Goodness-of-Fit Criteria}

The sixth step is to assess the goodness-of-fit to determine how far the hypothesized model is Fit with the data sample [27]. The results of goodness-of-fit showed in Table 6.

Table 6. Goodness-of-fit Index Test Results

\begin{tabular}{|l|l|l|l|}
\hline The goodness of fit index & Cut-off value & Research Model & Model \\
\hline Significant probability & $\geq 0.05$ & 0,000 & Less Fit \\
\hline Chi-Squares & 284,659 & 379,587 & Less Fit \\
\hline RMSEA & $\leq 0.08$ & 0.060 & Good Fit \\
\hline GFI & $\geq 0.90$ & 0.834 & Less Fit \\
\hline AGFI & $\geq 0.80$ & 0.798 & Less Fit \\
\hline CMIN / DF & $\leq 2.00$ & 1,537 & Good Fit \\
\hline TLI & $\geq 0.90$ & 0.953 & Good Fit \\
\hline CFI & $\geq 0.90$ & 0.958 & Good Fit \\
\hline
\end{tabular}

Table 6 shows the results of the goodness-of-fit test. The model results show that the RMSEA, CMIN / DF, TLI, and CFI criteria show a good fit. Referring to the parsimony principle, the overall model can be good if it meets one or two criteria. Thus the results of the goodness-of-fit test on the standard model used in this study indicate that the observed data follows the theory or model.

\section{Step 7: Interpret the Hypothesis Estimates}

The seventh step is to interpret and estimate the model. The final model estimation showed in Figure 4. It is the last model estimate that shows the results of the direct effect value between variables. The relationship between the direct and the indirect effect will be explained in the subsequent explanation.

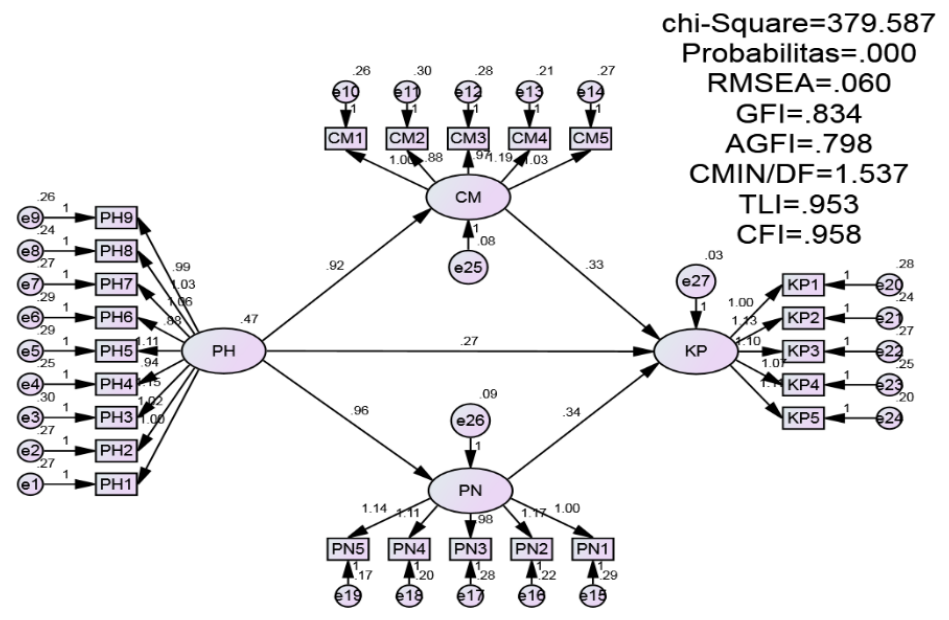

Fig 4. Value of Direct Influence between Variables 
Table 7. Relationship between Variable

\begin{tabular}{|l|l|l|l|l|l|}
\hline No. & Hypothesis & CR & $\mathbf{P}$ & Limit & Information \\
\hline 1. & Green marketing positively affects brand image. & $\mathbf{1 0 , 0 8 6}$ & $\mathbf{0 . 0 0 0}$ & 0.05 & Supported \\
\hline 2. & $\begin{array}{l}\text { Brand image positively affects purchasing } \\
\text { decisions. }\end{array}$ & $\mathbf{2 , 7 0 2}$ & $\mathbf{0 . 0 0 7}$ & 0.05 & Supported \\
\hline 3. & $\begin{array}{l}\text { Green marketing has a significant effect on } \\
\text { perceived value. }\end{array}$ & $\mathbf{1 0 , 0 6 4}$ & $\mathbf{0 . 0 0 0}$ & 0.05 & Supported \\
\hline 4. & $\begin{array}{l}\text { Perceived value positively affects purchasing } \\
\text { decisions. }\end{array}$ & $\mathbf{3 , 0 7 0}$ & $\mathbf{0 . 0 0 2}$ & 0.05 & Supported \\
\hline 5. & $\begin{array}{l}\text { Green marketing positively affects purchasing } \\
\text { decisions. }\end{array}$ & $\mathbf{1 , 9 8 9}$ & $\mathbf{0 . 0 4 7}$ & 0.05 & Supported \\
\hline
\end{tabular}

The following explains the results of hypothesis testing based on the statistical test results shown in Table 7.

Hypothesis 1 proposed the relationship between green marketing and brand image. Our results showed the value of $\mathrm{cr}$ is 10.086 . It indicated that the relationship between green marketing and brand image is positive and implies the higher the influence of green marketing, the higher the brand image generated. The P-value is $0.000<0.05$, which means significant, so that our first hypothesis (H1), which proposed that green marketing has a significant positive effect on brand image, is supported. Therefore, green marketing positively affects brand image.

Hypothesis 2 predicts the relationship between brand perception and buying decisions. Based on the critical value of $\mathrm{cr}$ is 2.702 , it implies that the relationship between brand image and purchasing decisions is positive. It means that the higher the influence of the brand image, the higher the purchase decision. The result of P-value $0.007<0.05$ showed a significant impact. Therefore, our second hypothesis $(\mathrm{H} 2)$, which proposed that brand image positively affects purchasing decisions, is supported. TheConsequentlye concluded that brand image positively affects purchase decisions.

Hypothesis 3 affirmed that green marketing affects perceived value. Our findings showed the value of $\mathrm{cr}$ is 10.064 , and it implies a positive relationship between green marketing and perceived value. The higher the effect of green marketing, the higher the perceived value. The P-value is $0.000<0.05$ implies a significant result. Therefore, our third hypothesis (H3), which proposed that green marketing has a significant positive effect on perceived value, is supported. Thus, green marketing positively influences perceived value.

Hypothesis 4 proposed the relationship between perceived value and purchasing decisions. Results of our data analysis got the value of $\mathrm{cr}$ is 3.070. It shows that the relationship between perceived value and purchasing decisions is positive, which means that the higher the effect of perceived value, the higher the purchase decisions. The P-value is $0.002<0.05$, showed significant result. Hence, our fourth hypothesis (H4), which stated perceived value has a significant positive effect on purchasing decisions, is supported. We concluded that perceived value positively affects purchasing decisions.

Hypothesis 5 predicts the relationship between green marketing and purchasing decisions. Our statistical analysis showed the value of $\mathrm{cr}$ is 1.989. It offers a positive relationship between green marketing and purchasing decisions, which means the higher the effect of green marketing, the higher the purchase decisions. The P-value is 0.047 $<0.05$, which means that it is significant, so that our fifth hypothesis (H5), which predicted that green marketing has a significant positive effect on purchasing decisions, is supported. Hence, we conclude that there is a significant and positive influence of green marketing on purchasing decisions. 


\subsection{Discussion}

Our results showed that all of the proposed hypotheses (H1), (H2), (H3), (H4), and (H5) are supported. The discussion about the description of each relationship is as follows:

Hypothesis one (H1), which suspects green marketing has a significant positive effect on brand image, is supported. Therefore, we summarized a substantial and positive influence of green marketing on the brand image. These findings support Jeong et al. [18], stating that customers' perceptions of green practices positively influence a green image. This finding also supports Grant [17], which says that green marketing aims to communicate that the brand or company cares about the environment to create a positive image for consumers. We proved that the higher the effect of green marketing, the higher the brand image. Good green marketing will increase the consumers' belief that the product has a good image. Thus, our study result could be an idea for marketers to continuously develop a green marketing strategy to influence a positive brand image in the mind of their consumers.

Hypothesis two (H2), which stated brand image has a significant positive effect on purchasing decisions, is supported. We concluded that there is a positive influence of the brand image on buying decisions of consumers. Our findings are in line with the results of Devi (2014), which proves that brand image positively affects purchasing decisions. Kotler and Keller [8] state that the brand image is one of the vital components in purchasing decisions. Consumers can decide to buy a beneficial product and have a good image of the surrounding environment. Our study proves that the higher the influence of the brand image, the higher the purchasing decisions generated. A good brand image of the product creates consumers purchasing decisions. Thus, our results may give insight to marketers to continuously attempt to improve a consumers' good brand image, which increases buying decisions.

Hypothesis three (H3), which proposed green marketing positively affects perceived value, is supported. We concluded that there is an influence between green marketing on consumers' perceived value. These findings support the research results from Confente et al. [21], which identified that a higher level of green self-identity leads to a higher level of the perceived value of a product. Pujari et al. [20] also argue that green marketing will positively impact the company's relationship with customers and increase positive perceptions of customers. Our study proves that the higher the effect of green marketing, the higher the perceived value. The theme of saving the environment will increase the positive value of consumers. Thus, customers will have a good perception of the brand. This finding might inspire marketers to continuously develop green marketing strategies by caring more about the environment to increase customer perception.

Hypothesis four (H4) which stated that perceived value has a significant positive effect on purchasing decisions, is supported. We concluded that perceived value positively affects buying decisions. A positive perceived value will convince consumers to buy. This study proves that the higher the effect of perceived value, the higher the perceived valueconsumers with a positive perception of a product are more likely to purchase. Thus, our results may inspire marketers to consistently make reasonable efforts to introduce the product values to influence the consumer purchase decision.

Hypothesis five (H5), which predicts green marketing positively affects purchasing decisions, is supported. We then concluded that there is an effect of green marketing on consumer purchasing decisions. This finding supports the results of Chen et al. [25], which state that green innovation activities improve brand image and influence consumers' purchase decisions, effectively achieve brand realization, and enhance brand competitiveness and market share. Our study proves that the higher the effect of green marketing, the higher the purchasing decision. Consumers aware of maintaining environmental quality will always choose to use friendly and safe products for their 
environment. It will reduce the risk of damage to the surrounding environment. Thus, our results may give marketers insight into constantly developing green marketing strategies to raise consumers' awareness, which will increase consumer purchasing decisions [28].

\section{Conclusions}

Based on the results of the research and discussion in the previous section, we conclude the following ideas: 1) green marketing positively affect brand image, 2) brand image has a significant positive impact on purchasing decisions, 3) green marketing has a significant positive effect on perceived value, 4). perceived value positively affects the brand image, and finally 5). purchasing decisions and green marketing have a significant positive effect on purchasing decisions. Therefore, all of our proposed hypotheses were supported with the data of our research. We expect our findings could inspire marketers to realize the importance of developing and practicing the green marketing program to achieve their marketing objective and contribute to the sustainability of society and the environment.

\section{Research Limitation and Suggestions}

The research setting is limited to one green marketing brand and limited sample size. Broader research setting with a more significant sample may increase the generalizability of the results. We propose the subsequent research to consider using multi-products that use green marketing programs and, therefore, will involve a greater sample size. We expect that the results will have greater generalizability and richer information.

\section{References}

1. D. K. Junaedi and I. Fatmawati, “Anteseden Pembelian Produk Hijau," J. Manaj. Pemasar. dan Jasa, vol. 9, no. 1, pp. 175-186, 2016.

2. I. Fatmawati, B. S. Dharmmesta, B. M. Purwanto, and S. S. Nugroho, "Promoting young adults to perform energy-saving behavior through message framing: A lesson learned from Indonesia," Acad. Strategy. Manag. J., vol. 17, no. 5, p. 6104, 2018.

3. P. H. Tsai, G. Y. Lin, Y. L. Zheng, Y. C. Chen, P. Z. Chen, and Z. C. Su, "Exploring the effect of Starbucks' green marketing on consumers' purchase decisions from consumers' perspective," J. Retail. Consum. Serv., vol. 56, no. April, p. 102162, 2020.

4. D. M. DI Hawkins, Building Marketing Strategy Consumer Behavior. New York: McGraw-Hill, 2010.

5. B. Mayank and J. Amit, "Green marketing: A study of consumer perception and preferences in India," Electron. Green J., vol. 1, no. 36, pp. 1-20, 2013.

6. M. J. Polonsky, "An Introduction To Green Marketing," Electron. Green J., vol. 1, no. 2, 1994.

7. P. Singh, "Green Marketing: Opportunity For Innovation And Sustainable Development." 2010.

8. B. Kotler, P., Keller, K. L., Manceau, D., \& Dubois, Marketing Management 15e édition. New Jersy: Pearson Education, 2016.

9. X. G. Li, X. Wang, and Y. J. Cai, "Corporate-, product-, and user-image dimensions and purchase intentions: The mediating role of cognitive and affective attitudes," $J$. Comput., vol. 6, no. 9, pp. 1875-1879, 2011.

10. A. Plumeyer, P. Kottemann, D. Böger, and R. Decker, "Measuring brand image: a 
systematic review, practical guidance, and future research directions," Rev. Manag. Sci., vol. 13, no. 2, pp. 227-265, 2019.

11. H. Zameer, Y. Wang, and H. Yasmeen, "Reinforcing green competitive advantage through green production, creativity, and green brand image: Implications for cleaner production in China," J. Clean. Prod., vol. 247, 2020.

12. M. F. Chen and C. L. Lee, "The impacts of green claims on coffee consumers' purchase intention," Br. Food J., vol. 117, no. 1, pp. 195-209, 2015.

13. J. Sánchez, L. Callarisa, R. M. Rodríguez, and M. A. Moliner, "Perceived value of the purchase of a tourism product," Tour. Manag., vol. 27, no. 3, pp. 394-409, 2006.

14. W. Ahmad and Q. Zhang, "Green purchase intention: Effects of electronic service quality and customer green psychology," J. Clean. Prod., vol. 267, p. 122053, 2020.

15. P. Kumar and B. M. Ghodeswar, "Factors affecting consumers' green product purchase decisions," Mark. Intell. Plan., vol. 33, no. 3, pp. 330-347, 2015.

16. K. Ramesh, R. Saha, S. Goswami, Sekar, and R. Dahiya, "Consumer's response to CSR activities: Mediating role of brand image and brand attitude," Corp. Soc. Responsib. Environ. Manag., vol. 26, no. 2, pp. 377-387, 2019.

17. J. Grant, The green marketing manifesto. England: John Wiley \& Sons.

18. E. H. Jeong, S. C. Jang, J. Day, and S. Ha, "The impact of eco-friendly practices on green image and customer attitudes: An investigation in a café setting," Int. J. Hosp. Manag., vol. 41, pp. 10-20, 2014.

19. N. Mohd Suki, "Green product purchase intention: impact of green brands, attitude, and knowledge," Br. Food J., vol. 118, no. 12, pp. 2893-2910, 2016.

20. D. Pujari, G. Wright, and K. Peattie, "Green and competitive influences on environmental new product development performance," J. Bus. Res., vol. 56, no. 8, pp. 657-671, 2003.

21. I. Confente, D. Scarpi, and I. Russo, "Marketing a new generation of bio-plastics products for a circular economy: The role of green self-identity, self-congruity, and perceived value," J. Bus. Res., vol. 112, no. October 2019, pp. 431-439, 2020.

22. M. Kumar and C. H. Noble, "Beyond form and function: Why do consumers value product design?" J. Bus. Res., vol. 69, no. 2, pp. 613-620, 2016.

23. S.-I. Wu and Y.-J. Chen, "The Impact of Green Marketing and Perceived Innovation on Purchase Intention for Green Products," Int. J. Mark. Stud., vol. 6, no. 5, pp. 81100, 2014.

24. E. M. Okada and E. L. Mais, "Framing the 'Green' alternative for environmentally conscious consumers," Sustain. Accounting, Manag. Policy J., vol. 1, no. 2, pp. 222234, 2010.

25. L. Chen, K. Qie, H. Memon, and H. M. Yesuf, "The empirical analysis of green innovation for fashion brands, perceived value and green purchase intention-mediating and moderating effects," Sustain., vol. 13, no. 8, 2021.

26. U. Sekaran and R. Bougie, Research methods for business: A skill-building approach. John Wiley \& Sons, 2019.

27. J. Hair, Multivariate Data Analysis, 7th ed. New Jersey: Prentice-Hall, 2010.

28. Z. Rozaki, Susanawati, D. Rina Kamardiani, and A. Kartika Huda, Consumer Preferences for Fresh and Frozen Local Beef in Sleman Regency, Indonesia. in E3S Web Conf. (2021). 